\title{
KAJIAN AKSESIBILITAS DAN POLA PEMASARAN MARKISA (Passiflora Ligularis) DI KECAMATAN LEMBAH GUMANTI DAN KECAMATAN DANAU KEMBAR KABUPATEN SOLOK
}

\author{
Jeli Herianto ${ }^{1}$, Paus Iskarni ${ }^{2}$, Nofrion ${ }^{3}$ \\ Program Studi Pendidikan Geografi \\ Fakultas Ilmu Sosial Universitas Negeri Padang \\ Email: Jeliherianto@gmail.com
}

\begin{abstract}
Abstrak
Artikel ini bertujuan untuk mendeskripsikan aksesibilitas petani menuju lahan markisa, aksesibilitas petani menuju pemasaran dan pola difusi pemasaranya. Penelitian dilakukan di Kecamatan Lembah Gumanti dan Kecamatan Danau Kembar. Jenis penelitian deskriptif kuantitatif dengan subjek petani markisa kedua kecamatan berjumlah 218 orang. Sampel penelitian diambil sebanyak $30 \%$ dari populasi yaitu 65 orang. Sampel diambil dengan teknik random sampling. Analisis data dilakukan dengan statistik deskriptif persentase. Hasil penelitian menunjukan aksesibilitas menuju lahan markisa a) sebagian besar petani menempuh jarak 0-2,3 km Kecamatan Lembah Gumanti, dan Kecamatan Danau Kembar sebagian besar pada jarak 2,3 -4,6 km. b) Jenis transportasi kedua kecamatan umumnya berjalan kaki. c) Kondisi jalan kedua kecamatan umumnya jalan tanah setapak. d) Biaya perjalanan petani kedua kecamatan umumnya tidak ada. e) Waktu tempuh kedua kecamatan umumnya 20-60 menit. (2) Aksesibilitas menuju pemasaran markisa dalam kondisi a) jarak pemasaran kedua kecamatan umumnya antara $0-3,3 \mathrm{~km}$. b) Kondisi jalan Kecamatan Lembah Gumanti sebagian besar jalan tanah, dan Kecamatan Danau Kembar sebagian besar melewati jalan tanah, lalu kerikil dan aspal. c) Biaya pemasaran kedua kecamatan umumnya di kisaran Rp. 20.000 - Rp 50.000. d) Waktu tempuh kedua kecamatan umumnya 20-60 menit. (3) Pola difusi pemasaran markisa kedua kecamatan sama sama difusi ekspansi tipe menjalar dan difusi relokasi.
\end{abstract}

\section{Kata Kunci : Aksesibilitas, Pemasaran, Markisa}

\section{Abstract.}

Aims of this study is to describe the accessibility of farmers to the passion fruit fields, farmers accessibility to marketing and marketing diffusion pattern. The research was conducted in District of Lembah Gumanti and District Danau Kembar. The type of this research is descriptive quantitative research with the subject is the passion fruit farmers of both sub-districts amounted to 218 people. The sample was taken as many as $30 \%$ of the population which is 65 people. Samples were taken by random sampling technique. Data analysis is done by descriptive statistic percentage. The results showed the accessibility to passion fruit field a) most of farmers travel distance 0-2,3 km District of Lembah Gumanti, and District of Danau Kembar mostly at distance of 2,3 -4,6 km. b) The type of transportation of the two sub-districts is generally only by foot. c) The condition of the roads of both sub-districts is generally a soil track. d) The cost of farmers' travel in both sub-districts is generally absent. e) The travel time of both sub-districts is generally 20-60 minutes. (2) Accessibility to passion fruit marketing under conditions a) the marketing distance of the two sub-districts is generally between $0-3.3 \mathrm{~km}$. b) Conditions of District of Lembah Gumanti are mostly soil roads, and District of Danau Kembar mostly pass through soil road, then gravel and asphalt. c) The marketing costs of both sub-districts are generally in the range of Rp. 20,000 - Rp 50,000. d) The travel time of both sub-districts is generally 20-60 minutes. (3) Pattern of diffusion of passion fruit marketing of second subdistrict diffusion type expansion and diffusion of relocation diffusion.

Keywords: Accessibility, Marketing, Passion fruit”

\footnotetext{
${ }^{1}$ Mahasiswa Program Studi Pendidikan Geografi

${ }^{2}$ Dosen Jurusan Geografi Fakultas Ilmu Sosial Universitas Negeri Padang.

Pembimbing 1 : Dr. Paus Iskarni, M.Pd; Pembimbing 2: Nofrion, S.Pd, M.Pd 


\section{A. PENDAHULUAN}

Indonesia sebagai negara dengan iklim tropis memiliki sumber daya alam yang sangat potensial untuk dikembangkan disektor pertanian, salah satunya pertanian holtikultura. Hortikultura adalah segala hal yang berkaitan dengan buah, sayuran, bahan obat nabati, dan florikultura, termasuk di dalamnya jamur, lumut, dan tanaman air yang berfungsi sebagai sayuran, bahan obat nabati, dan bahan estetika (UU No 13 tahun 2010 ayat 1). Holtikultura memegang peranan penting bagi pembangunan pertanian di Indonesia, buah buahan salah satunya. Buah-buahan yang diyakini sangat penting bagi proses metabolisme tubuh karna buah salah satu unsur makanan yang dianjurkan dalam pola makan empat sehat lima sempurna. Karena didalam buah terdapat kandungan gizi, vitamin dan mineral yang pada umumnya sangat baik untuk dikonsumsi setiap hari dibandingkan dengan suplemen kimia yang dijual di pasaran (Dinas Kesehatan Sumatera Barat, 2010).

Seiring dengan berlakuknya Undang-Undang No 23 tahun 2014 tentang pemerintah daerah, maka masing-masing kabupaten/kota berwenang mengembangkan setiap potensi yang dimiliki daerahnya. Salah satu bentuk kebijakan pembangunan ekonomi daerah dalam rangka mengembangkan potensi setiap daerah itu adalah didasarkan pada prinsip keuntungan kompetitif. Salah satu caranya adalah mengembangkan komoditas unggulan. Dalam hal ini pemerintah mendorong daerah untuk mengembangkan satu atau dua komoditi utama yang mempunyai potensi besar dan mempunyai daya saing tinggi sesuai dengan keuntungan kompetitif yang dimiliki oleh daerah yang bersangkutan (Syafrizal, 2009).

Provinsi Sumatera Barat sebagai salah satu daerah yang mempunyai potensi ekonomi yang besar di sektor pertanian, terutama dalam sub-sektor tanaman pangan dan hortikultura, didukung juga oleh potensi sumberdaya lahan di Sumatera Barat cukup besar. Luas provinsi Sumatera Barat \pm 42.226,64 $\mathrm{km}^{2}$ dan telah dimanfaatkan untuk lahan pertanian sekitar 20,0\%, sisanya sebagian besar merupakan hutan yang masih berpeluang untuk pengembangan sektor pertanian (Bappeda Sumbar, 2013). Posisi Sumatera Barat sangat strategis, terletak di tengah dan bagian barat pulau Sumatera. Dari segi iklim cukup mendukung pengembangan sektor pertanian khususnya buah-buahan rakyat.

Melihat potensi itu semua dinas tanaman pangan dan hortikultura propinsi Sumatera Barat menetapkan visi pembangunan pertaniannya secara arif dan bijak sesuai dengan dukungan sumberdaya alam dan sumberdaya manusia yang dimiliki. Visi itu adalah "Terwujudnya rumah tangga petani yang sejahtera". Visi ini selaras dan turut mendukung pewujudan visi pembangunan sektor pertanian nasional yaitu "Terwujudnya pertanian industrial unggul berkelanjutan yang berbasis sumberdaya lokal untuk meningkatkan kemandirian pangan, nilai tambah, daya saing, ekspor dan kesejahteraan petani”. 
Dalam upaya mewujudkan visi tersebut maka ada enam misi yang harus dijadikan patokan dalam menetapkan strategi pembangunan pertanian, yaitu:

1) meningkatkan pemberdayaan petani 2) meningkatkan kompetensi aparatur 3) meningkatkan esiensi dan mutu produksi serta daya saing 4) mengembangkan pertanian organik 5) mengoptimalkan pemanfaatan sumberdaya lokal dan sarana prasarana pertanian 6) meningkatkan kelembagaan permodalan dan peluang pasar. Keenam misi ini telah mengarahkan pengambil kebijakan untuk menyusun kegiatan-kegiatan pembangunan pertanian secara bertahap dan berkelanjutan sesuai dengan sumberdaya yang dimiliki. Khusus untuk pengembangan tanaman buah buahan, pemerintah Sumatera Barat lebih menekankan kepada pengembangan buah-buahan lokal spesifik lokasi salah satunya adalah buah markisa.

Kabupaten Solok merupakan satu-satunya kabupaten di Sumatera Barat yang cocok untuk budidaya markisa, karena memenuhi syarat-syarat untuk pertumbuhaan markisa. Daerah yang membudidayakan di Kabupaten Solok diantaranya adalah Kecamatan Lembah Gumanti, Kecamatan Danau Kembar, dan Kecamatan Gunung Talang. Potensi itulah yang menjadikan markisa salah satu komoditas hortikultura buah-buahan andalan Kabupaten Solok. namun meskipun mempunyai potensi yang besar akan menjadi kendala jika kebijakan pembangunan daerah tidak memberikan perhatian yang cukup dalam perencanaan pembangunan, khususnya perencanaan pembangunan transportasi untuk meningkatkan aksesibilitas masyarakat pada kawasan pertanian masyarakat perdesaan. Menurut Magribi (2004) dengan meningkatnya aksesibilitas, diharapkan kualitas hidup masyarakat perdesaanpun akan bertambah pula. Lahan pertanian yang kurang subur dapat ditingkatkan kesuburannya dengan sistem pengelolaan lahan dan penggunaan pupuk yang baik, serta pemanfaatan bibit unggul; akses yang baik, akan meningkatkan kualitas pemanfaatan dan pengembangan sumber daya alam dan sumber daya manusia, serta perekonomian masyarakat.

Aksesibilitas merupakan salah satu komponen dal subsistem hulu yang diharapkan dapat mendukung subsitem jalan usaha tani, subsistem pengolahaan dan subsitem pemasaran hasil pertanian. Saat ini banyak lokasi lahan pertanian yang belum mempunyai akses yang memadai sehingga dapat menghambat dalam pengangkutan sarana usaha tani dan mengangkut hasil produk dari lahan menuju tempat lainya seperti pemukiman, tempat penampung sementara atau tempat lainya (Zulkifli, 2015). Dalam rangka penerapan otonomi daerah, maka diharapkan kawasankawasan dengan potensi yang besar diberikan peluang untuk berkembang dengan cara memberikan bantuan pembangunan sarana dan prasarana penunjang, agar potensi tersebut dapat dimanfaatkan semaksimal mungkin untuk membantu pelaksanaan pembangunan

Namun berdasarkan orbservasi di lapangan ditemukan beberapa kendala 
dalam usaha tani markisa. Kendala itu berupa sarana dan prasarana transportasi yang kurang memadai yang menyebabkan petani kesulitan dalam pengangkutan sarana usaha tani dan pengangkutan hasil produk dari lahan menuju tempat lainya seperti pemukiman, tempat penampung sementara atau tempat lainya barang. Pada musim penghujan petani sering mengalami kerugian karena hasil produksi pertanian tidak dapat diangkut semestinya karena kondisi medan yang berbukit bukit dengan jalan tanah yang licin. Selain itu sarana produksi (tiang, kawat, tali, dan kayu penyangga) mahal sedangkan nilai jual rendah sedangkan masa panen lama. Ditambah lagi dengan banyaknya dari petani yang mengeluhkan tanaman mereka banyak yang mati muda, dimana penyakit ini menyerang pucuk dari markisa yang menyebabkan tanaman layu dan kemudian mati. Sehingga banyak petani yang alih tanam ke tanaman sayur sayuran yang masa panenya cepat.

Masalah lainya adalah sifat buah markisa yang lunak mudah rusak, cepat busuk, berat dan memerlukan banyak tempa maka di perlukannya cara penangganan produksi dengan melalui pemasaran buah markisa yang baik agar buah markisa yang telah dipanen oleh petani tetap bagus dan tidak rusak sesampainya ke konsumen. Semakin panjang rantai pemasaran markisa tersebut mengakibatkan penurunan mutu dan biaya markisa tersebut. Maka diperlukanlah mengetahui kemana saja pemasaran markisa tersebut. Berdasarkan uraian diatas maka penulis melakukan penelitian mengenai
"Kajian Aksesibilitas dan Pola Pemasaran Markisa (Passiflora Ligularis) di Kecamatan Danau Kembar dan Kecamatan Lembah Gumanti”.

Tujuan penelitian ini adalah untuk mendeskripsikan aksesibilitas menuju lahan markisa, mendeskripsikan aksesbilitas menuju pemasaran markisa, dan medeskripsikan pola difusi pemasaran markisa di Kecamatan Lembah Gumanti dan Kecamatan Danau Kembar.

\section{B. METODE PENELITIAN}

Jenis penelitian adalah penelitian deskriptif dengan pendekatan kuantitatif. Deskriptif Kuantitatif salah satu bentuk dari penelitian yang bertujuan untuk menerangkan, menggambarkan gejalagejala, fakta- fakta dan sifat populasi pada daerah penelitian, menerangkan variabel yang telah diajukan dengan maksud memberikan gambaran mengenai keadaan yang ada pada daerah penelitian (Arikunto, 2006). Populasi penelitian adalah semua petani markisa yang tersebar di Kecamatan Danau Kembar dan Kecamatan Lembah Gumanti sebanyak 218 orang. Pemilihan sampel dilakukan dengan cara random sampling dengan pengambilan $30 \%$ dari populasi.

Tabel 1. Jumlah Sampel Penelitian

\begin{tabular}{|c|c|c|c|c|}
\hline No & Kecamatan & $\begin{array}{c}\text { Jumlah Petani } \\
\text { Markisa (Orang) }\end{array}$ & $\begin{array}{c}\text { Persentase } \\
(\%)\end{array}$ & $\begin{array}{c}\text { Sampel Petani } \\
\text { Markisa (Orang) }\end{array}$ \\
\hline 1 & Danau Kembar & 90 & 30 & 27 \\
\hline 2 & Lembah Gumanti & 128 & 30 & 38 \\
\hline \multicolumn{2}{|r|}{ Jumlah } & 218 & 100 & 65 \\
\hline
\end{tabular}

Sumber : Pengolahaan Data Primer 2017

Data yang dihasilkan adalah tentang: 1) kondisi aksesibilitas menuju lahan markisa, 2) kondisi aksesiblitas menuju pemasaran markisa 3) pola difusi 
pemasaran markisa. Data dianalisis menggunakan formula berikut:

$$
\mathrm{P}=\frac{F}{N} \times 100 \%
$$

Keterangan:

$\mathrm{P}=$ Persentase

$\mathrm{F}=$ Frekuensi

$\mathrm{N}=$ Jumlah responden

Sumber: Sudjana (2007)

\section{HASIL DAN PEMBAHASAN}

Hasil yang telah didapatkan pada penelitian ialah sebagai berikut:

Aksesibilitas, Menurut Tamin (2000) adalah suatu ukuran kenyamanan atau kemudahan mengenai cara lokasi tata guna lahan berinterksi satu sama lain dan mudah atau susahnya lokasi tersebut dicapai melalui sistem transportasi. Untuk melihat kemudahhan dalam menjangkau semuanya itu, menurut Miro (2002) salah satu indikatornya adalah jarak. Semakin dekat jarak maka aksesnya semakin tinggi dan begitu juga sebaliknya jika jarak berjauhan maka akses termasuk rendah. Terkait aksesibilitas dalam penelitian yang dilakukan telah didapatkan hasil jarak menuju lahan markisa dan jarak menuju pemasaran markisa. Dimana untuk jarak menuju lahan markisa $50 \%$ petani menempuh jarak 0-2,3 km di Kecamatan Lembah Gumanti, sedangkan di Kecamatan Danau Kembar 48,1 \% menempuh jarak 2,3 -4,6 km.

Selanjutnya untuk aksesibilitas menuju pemasaran di Kecamatan Lembah Gumanti dan Kecamatan Danau Kembar pada umumnya menjawab jika jarak tempuh pemasaran mereka antara 0 $-3,3 \mathrm{~km}$. Namun menurut Tamin (2000) faktor jarak tidak dapat diandalkan karna pada kenyataanya bisa terjadi bahwa dua zona yang jaraknya berdekatan, tidak dapat dikatakan tinggi tingkat aksesnya apabila antara zona yang satu dengan yang lainya tidak terdapat jaringan transportasi yang menghubungkan serta memadai.Demikian pula sebaliknya dua zona yang berjauhan tidak dapat dikatakan aksesnya rendah antar zona tersebut terdapat jaringan prasarana jalan dan pelayanan armada angkutan yang cukup memadai. Selain jarak dan kondisi sarana dan prasarana transportasi waktu dan biaya juga masuk kedalam indikator aksesibilitas. Apabila antar kedua tempat memiliki waktu tempuh yang pendek maka dapat dikatakan kedua tempat itu memiliki aksesibilitas yang tinggi.

Berdasarkan pendapat Tamin tersebut telah didapatkan gambaran dari indikator yang telah dijelaskan sebelumnya yaitu jenis transportasi yang digunakan petani menuju lahan markisa di Kecamatan Lembah Gumanti dan Danau Kembar pada umumnya berjalan kaki. Ditambah dengan kondisi jalan menuju lahan markisa di kedua kecamatan pada umumnya yang masih jalan tanah. Waktu tempuh menuju lahan markisa di kedua kecamatan pada umumnya membutuhkan waktu $20-60$ menit. kemudian biaya yang dikeluarkan menuju lahan oleh petani markisa di Kecamatan Lembah Gumanti dan Kecamatan Danau Kembar pada umumnya tidak mengeluarkan biaya karna kebanyakan petani menuju lahan berjalan kaki.

Sementara itu aksesibilitas menuju pemasaran di Kecamatan Lembah 
Gumanti sebagian besar melewati jalan tanah tentu ini akan menyulitkan dalam proses pengangkutan. Sementara itu untuk Kecamatan Danau Kembar sudah lebih baik dari segi kondisi jalan yang sebagian besar adalah melewati jalan tanah, kerikil dan aspal. Kemudian biaya yang dikeluarkan petani setiap melakukan pemasaran markisa sebagian besar di dua kecamatan berada pada kisaran Rp. 20.000 - Rp 50.000. dengan membutuhkan waktu di kedua kecamatan sebagian besar yaitu 20-60 menit

Pola Difusi Pemasaran, Berhasil tidaknya usaha tersebut sangat tergantung pada keahliannya di bidang pemasaran, produksi, keuangan, dan sumber daya manusia. Selain itu panjangnya rantai pemasaran juga akan mempengaruhi usaha tani tersebut. Semakin panjang rantai pemasaran tentu akan mengakibatkan penurunan kualitas komoditas suatu pertanian. Oleh karena itu dalam penelitian ini diperlukan gambaran kemana saja pemasaran markisa

Tabel 2. Arah Pemasaran Markisa di Kecamatan Lembah Gumanti Tahun 2012

\begin{tabular}{|c|l|r|r|}
\hline No & \multicolumn{1}{|c|}{$\begin{array}{c}\text { Daerah } \\
\text { Pemasaran }\end{array}$} & \multicolumn{1}{c|}{$\begin{array}{c}\text { Jumlah } \\
\text { (f) }\end{array}$} & $\begin{array}{c}\text { Persentase } \\
(\%)\end{array}$ \\
\hline 1 & $\begin{array}{l}\text { Dalam } \\
\text { Kecamatan }\end{array}$ & 12 & 31,6 \\
\hline 2 & $\begin{array}{l}\text { Kecamatan } \\
\text { Danau Kembar }\end{array}$ & 4 & 10.5 \\
\hline 3 & $\begin{array}{l}\text { Kecamatan } \\
\text { Gunung talang }\end{array}$ & 15 & 39,5 \\
\hline 4 & Medan & 7 & 18,4 \\
\hline \multicolumn{2}{|c|}{ Jumlah } & 38 & 100 \\
\hline
\end{tabular}

Sumber: Data Primer 2017

Gambar 1. Arah Pemasaran Markisa Kecamatan Lembah Gumanti Tahun 2012

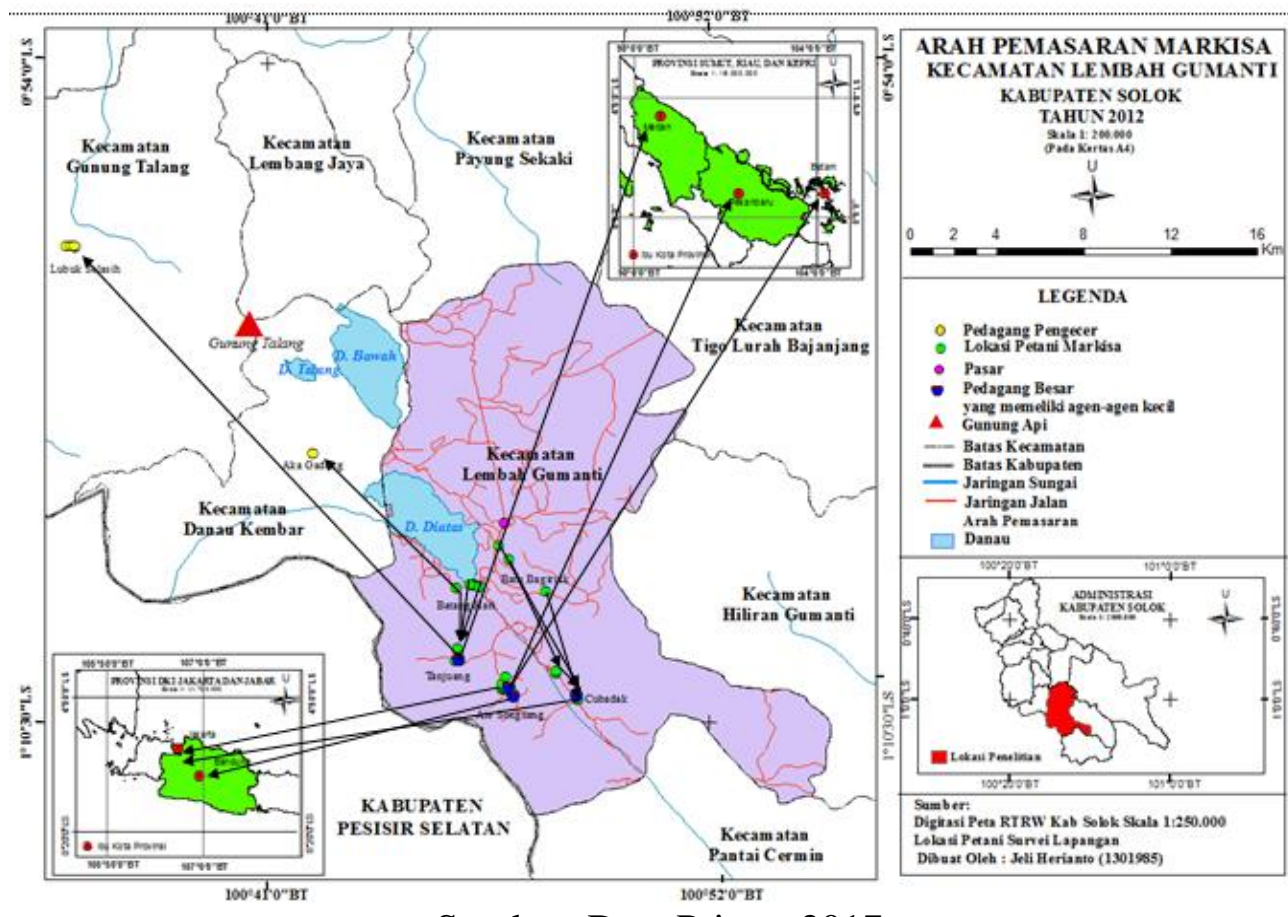

Sumber: Data Primer 2017

Berdasarkan peta arah pemasaran markisa di Kecamatan Lembah Gumanti pada tahun 2012 terlihat arah pemasaran markisa yang jangkauanya cukup luas. ini terlihat arah pemasaran seperti menuju Medan, Pekanbaru, Batam, Jakarta dan Bandung. Pada tahun 2012 petani menjual hasil markisa mereka melalui agen-agen yang tersebar di sekitar Kecamatan Lembah Gumanti. 
Agen agen inilah yang membawa hasil markisa petani. Hasil yang telah dikumpulkan di tingkat petani akan dimuat dalam sebuah truk yang nantinya akan dikirim kepulau jawa seperti Jakarta dan Bandung serta daerah lainya seperti Pekanbaru dan Batam.

Gambar 2. Arah Pemasaran Markisa di Kecamatan Lembah Gumanti Tahun 2017

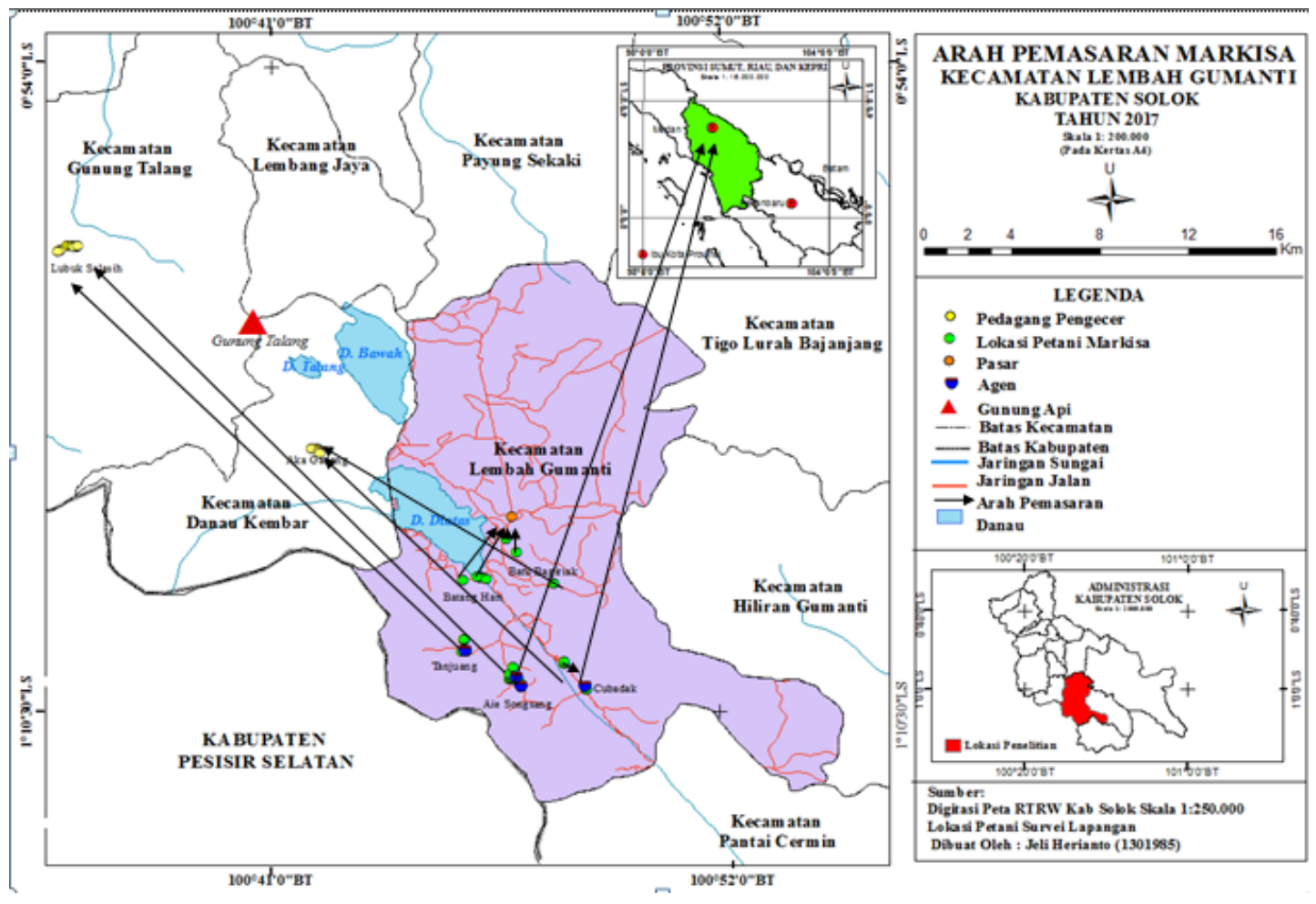

Sumber: Data Primer 2017

Berdasarkan peta diatas Jika dilihat arah pemasaran markisa di Kecamatan Lembah Gumanti dari dua tahun yang berbeda yaitu daerah pemasaran pada tahun 2012 dan daerah pemasaran pada tahun 2017. Disini terihat beberapa perubahaan dalam arah pemasaran. Jika kita lihat pada tahun 2012 arah pemasaran markisa cakupanya sangat luas meliputi arah seperti Jakarta dan Bandung, Pekanbaru, Batam,dan Medan. Kemudian jika dibandingkan dengan tahun 2017 terjadi perpindahaan arah dimana untuk daerah pemasaran menuju Jakarta, Bandung, Pekanbaru, dan Batam tidak ada lagi dikarenakan produksi markisa ditingkat petani mengalami penurunan dari tahun ketahun.
Tabel 3. Data Produksi Markisa di Kecamatan Lembah Gumanti Tahun 2010-2014

\begin{tabular}{|l|l|r|}
\hline No & Tahun & Produksi/Ton \\
\hline 1 & $2010-2011$ & 328.500 \\
\hline 2 & $2011-2012$ & 90.079 \\
\hline 3 & $2012-2013$ & 97.497 \\
\hline 4 & $2013-2014$ & 97.497 \\
\hline 5 & $2014-2015$ & 87.963 \\
\hline
\end{tabular}

Sumber: BPS Kabupaten Solok dalam Angka.

Pada tahun 2017 kebutuhaan produksi markisa hanya bisa memenuhi kebutuhaan dalam Kabupaten ini seiring terjadinya penurunan produksi markisa. Pemasaran kebanyakan tersebar di daerah-daerah wisata seperti Danau Kembar, Kebun Teh, dan Villa. Untuk permintaan biasanya tinggi pada saat hari libur lebaran. Saat ini banyak wisatawan yang datang mengunjungi obejk wisata yang ada di Kabupaten 
Gambar 3. Pola Difusi Pemasaran Markisa di Kecamatan Lembah Gumanti Tahun 2017

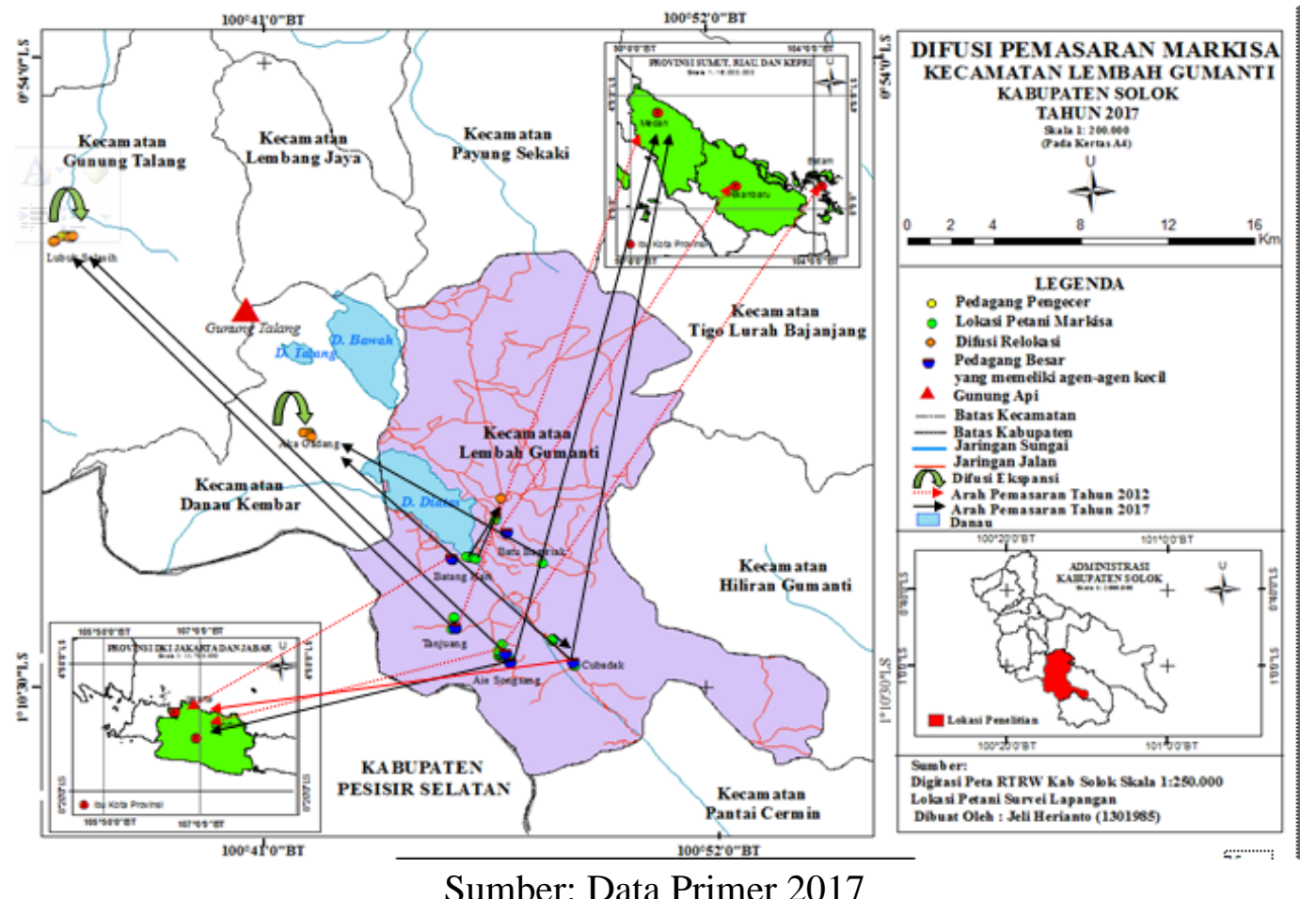

Berdasarkan peta di atas jika dilihat arah pemasaran markisa di Kecamatan Lembah Gumanti dari dua tahun yang berbeda yaitu daerah pemasaran pada tahun 2012 dan daerah pemasaran pada tahun 2017. Disini terihat beberapa perubahaan dalam arah pemasaran. Jika kita lihat pada tahun 2012 arah pemasaran markisa cakupanya sangat luas meliputi arah seperti Jakarta dan Bandung, Pekanbaru, Batam, dan Medan.

Kemudian jika dibandingkan dengan tahun 2017 terjadi perpindahaan arah dimana untuk daerah pemasaran menuju Jakarta, Bandung, Pekanbaru, dan Batam tidak ada lagi dikarenakan produksi markisa ditingkat petani mengalami penurunan dari tahun ketahun. Sementara untuk wilayah medan masih tetap. Artinya terjadi difusi relokasi (relocation diffusion). Difusi ini merupakan proses yang sama dengan penyebaran keruangan dimana informasi atau material yang didifusikan meninggalkan daerah yang lama dan berpindah atau ditampung di daerah yang baru. Dimana terlihat munculnya tempat-tempat pemasaran baru didalam Kecamatan seperti Pasar Alahan Panjang dan Kecamatan Gunung Talang. Sementara itu pemasaran menuju Kecamatan Gunung Talang terjadi pola difusi ekspansi. Difusi ini adalah suatu proses dimana informasi, material dan sebagainya menjalar melalui suatu populasi dari suatu daerah ke daerah yang lain.

Hal ini berarti bahwa terjadi penambahan jumlah anggota baru pada populasi antara periode dua waktu dan penambahan anggota baru tersebut 
mengubah pola keruangan populasi secara keseluruhan Tipe difusi yang terdapat di Kecamatan Lembah Gumanti ini adalah tipe menyebar dengan muncul tempat tempat baru disekitar tempat pemasaran markisa yang lama.

Sementara itu kecamatan tetangga yaitu Kecamatan Danau Kembar daerah pemasaran tidak seluas Kecamatan Lembah Gumanti. Hal ini terjadi karna dari segi jumlah petani serta produksi markisa kecamatan ini masih jauh dibawah Kecamatan Lembah Gumanti.

Tabel 4. Daerah Pemasaran Markisa di Danau Kembar pada tahun 2012

\begin{tabular}{|l|l|r|r|}
\hline No & \multicolumn{1}{|c|}{$\begin{array}{c}\text { Daerah } \\
\text { Pemasaran }\end{array}$} & \multicolumn{1}{c|}{$\begin{array}{c}\text { Jumlah } \\
\text { (f) }\end{array}$} & \multicolumn{1}{c|}{$\begin{array}{c}\text { Persentase } \\
(\%)\end{array}$} \\
\hline 1 & $\begin{array}{l}\text { Jawa (Jakarta } \\
\text { dan Bandung) }\end{array}$ & 15 & 55,6 \\
\hline 2 & Pekanbaru & 8 & 29,6 \\
\hline 3 & $\begin{array}{l}\text { Kecamatan } \\
\text { Gunung } \\
\text { Talang }\end{array}$ & 4 & 14,8 \\
\hline \multicolumn{2}{|l|}{ Jumlah } & 27 & 100 \\
\hline
\end{tabular}

Sumber: Data Primer 2017

Gambar 4. Arah Pemasaran Markisa di Kecamatan Danau Kembar Tahun 2012

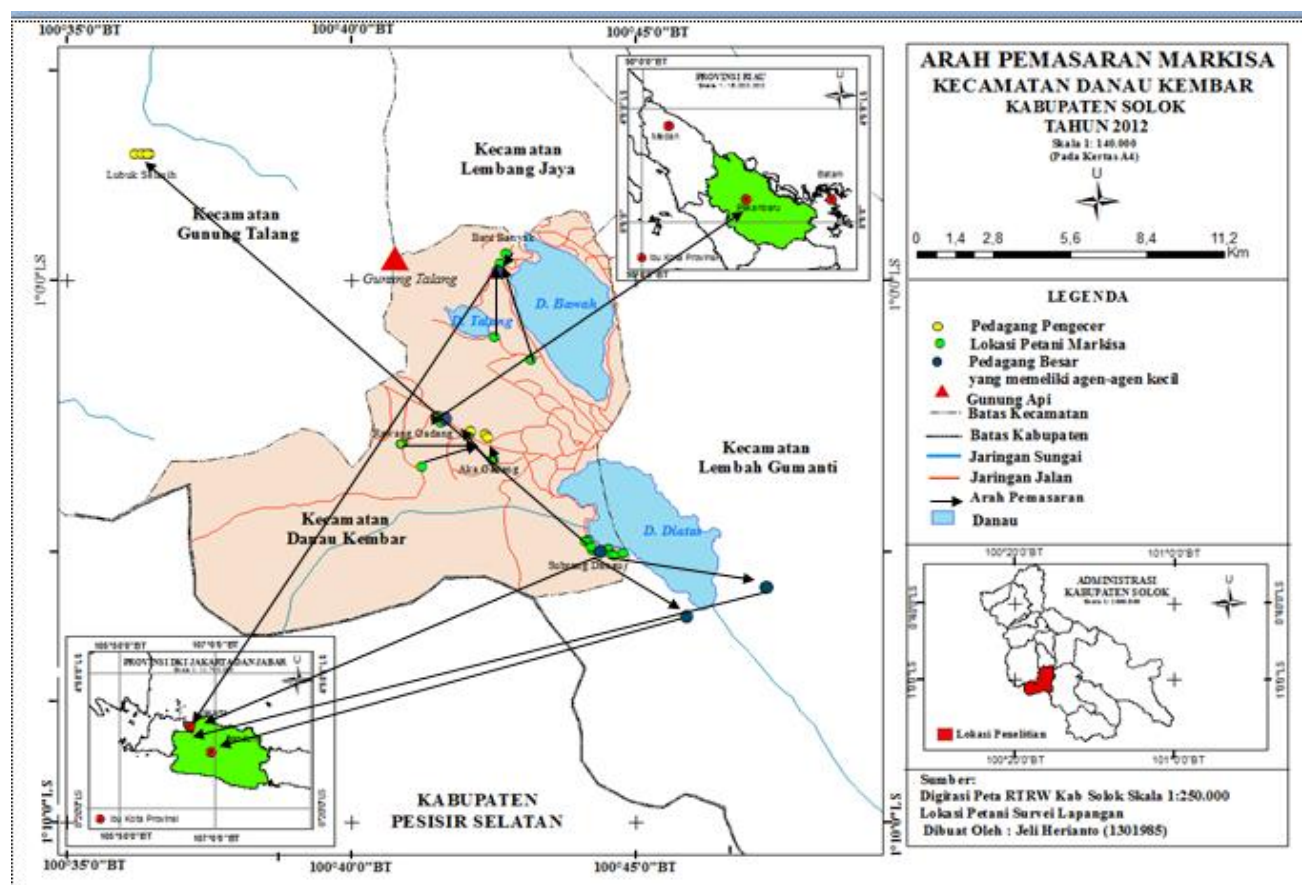

Sumber: Data Primer 2017

Berdasarkan peta di atas pada tahun 2012 terlihat arah jangkauan pemasaran yang cukup luas bahkan hingga mencapai pulau jawa seperti Jakarta dan Bandung. Pada tahun 2012 petani menjual hasil markisa mereka melalui agen-agen yang tersebar di sekitar Kecamatan Lembah Gumanti. Agen agen inilah yang membawa hasil markisa petani. Hasil yang telah dikumpulkan di tingkat petani akan dimuat dalam sebuah truk yang nantinya akan dikirim kepulau jawa seperti
Jakarta dan Bandung serta daerah lainya seperti Pekanbaru dan Batam. Menurut agen permintaan dari daerah-daerah luar Sumatera Barat biasanya di lakukan pemuatan berdasarkan permintaan pasar. Tingginya permntaan pasar ini tidak terlepas dari rasa buah markisa yang manis dan segar. Buah markisa selain di bisa dimakan langsung juga biasanya diolah oleh konsumen menjadi buah olahan seperti jus, puding, sirup dll. 
Gambar 5. Arah Pemasaran Markisa di Kecamatan Danau Kembar Tahun 2012

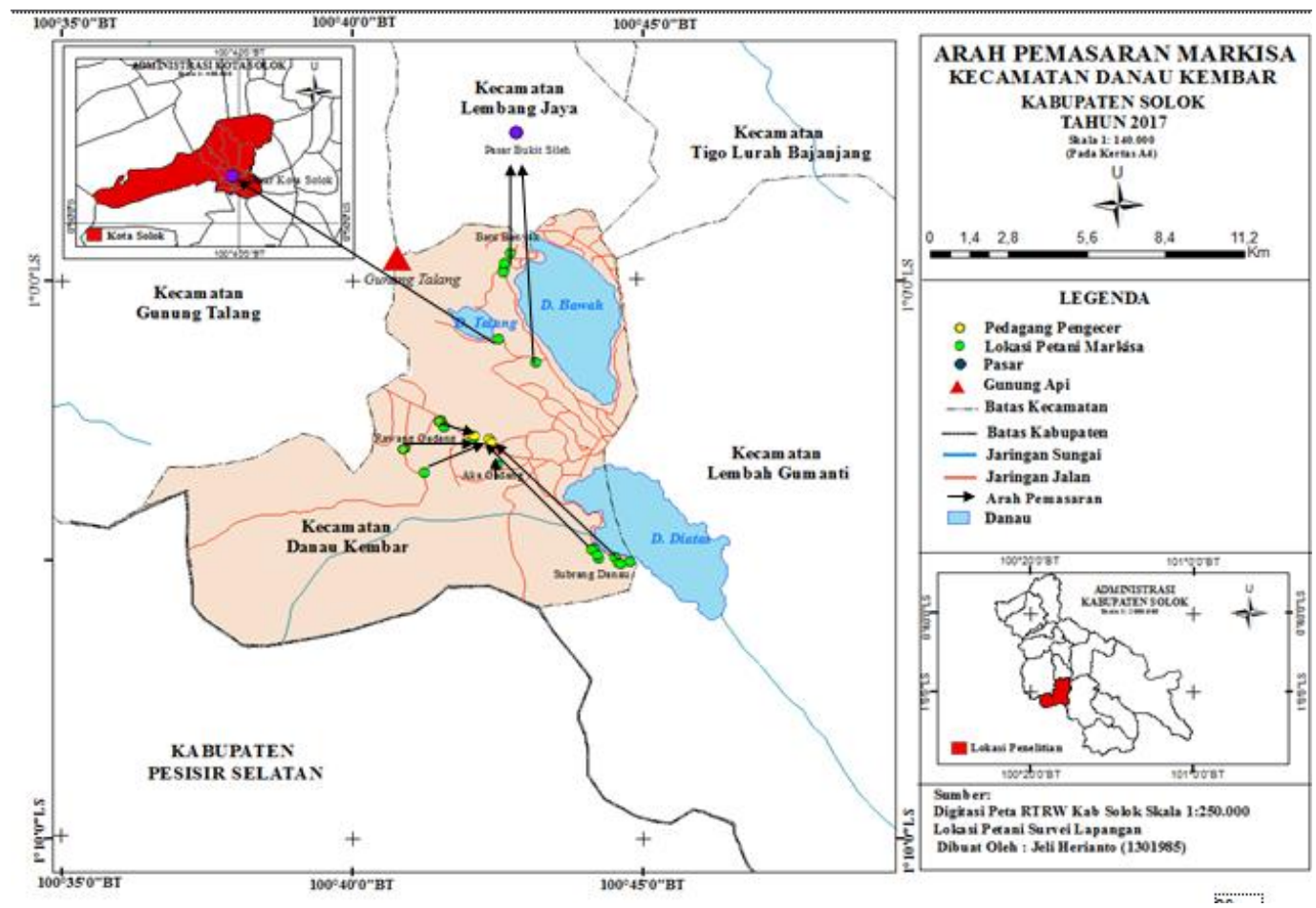

Sumber: Data Primer 2017

Berdasarkan peta di atas terlihat arah pemasaran markisa di Danau Kembar pada tahun 2017. Disini terihat beberapa perubahaan dalam arah pemasaran jika dibandingkan dengan tahun 2012. Tahun 2017 terjadi perpindahaan arah dimana untuk daerah pemasaran menuju Jakarta, Bandung, Pekanbaru, dan Batam tidak ada lagi dikarenakan produksi markisa ditingkat petani mengalami penurunan dari tahun ketahun.

Tabel 5. Produksi Markisa di Kecamatan Danau Kembar Tahun 2010-2014

\begin{tabular}{|l|l|r|}
\hline No & Tahun & Produksi/Ton \\
\hline 1 & $2010-2011$ & 29.877 \\
\hline 2 & $2011-2012$ & 21.309 \\
\hline 3 & $2012-2013$ & 16.761 \\
\hline
\end{tabular}

\begin{tabular}{|l|l|r|}
\hline 4 & $2013-2014$ & 19.236 \\
\hline 5 & $2014-2015$ & 4.143 \\
\hline
\end{tabular}

Sumber: Data Primer 2017

Pada tahun 2017 kebutuhaan produksi markisa hanya bisa memenuhi kebutuhaan dalam Kecamatan ini seiring terjadinya penurunan produksi markisa. rata-rata responden mengatakan bahwa banyaknya permintaan dalam Kecamatan akan markisa karna secara lokasi, Kecamatan Danau Kembar adalah kawasan wisata di Kabuaten Solok. Bahkan pedagang pengencer mencari markisa hingga ke Kecamatan lain seperti Kecamatan Lembah Gumanti dan Kecamatan Gunung Talang. Namun ada juga responden memilih menjual hasil markisa mereka kepasar langsung karna alasan harganya yang lebih tinggi.

Gambar 6. Difusi Pemasaran Markisa di Kecamatan Danau Kembar Tahun 2017 


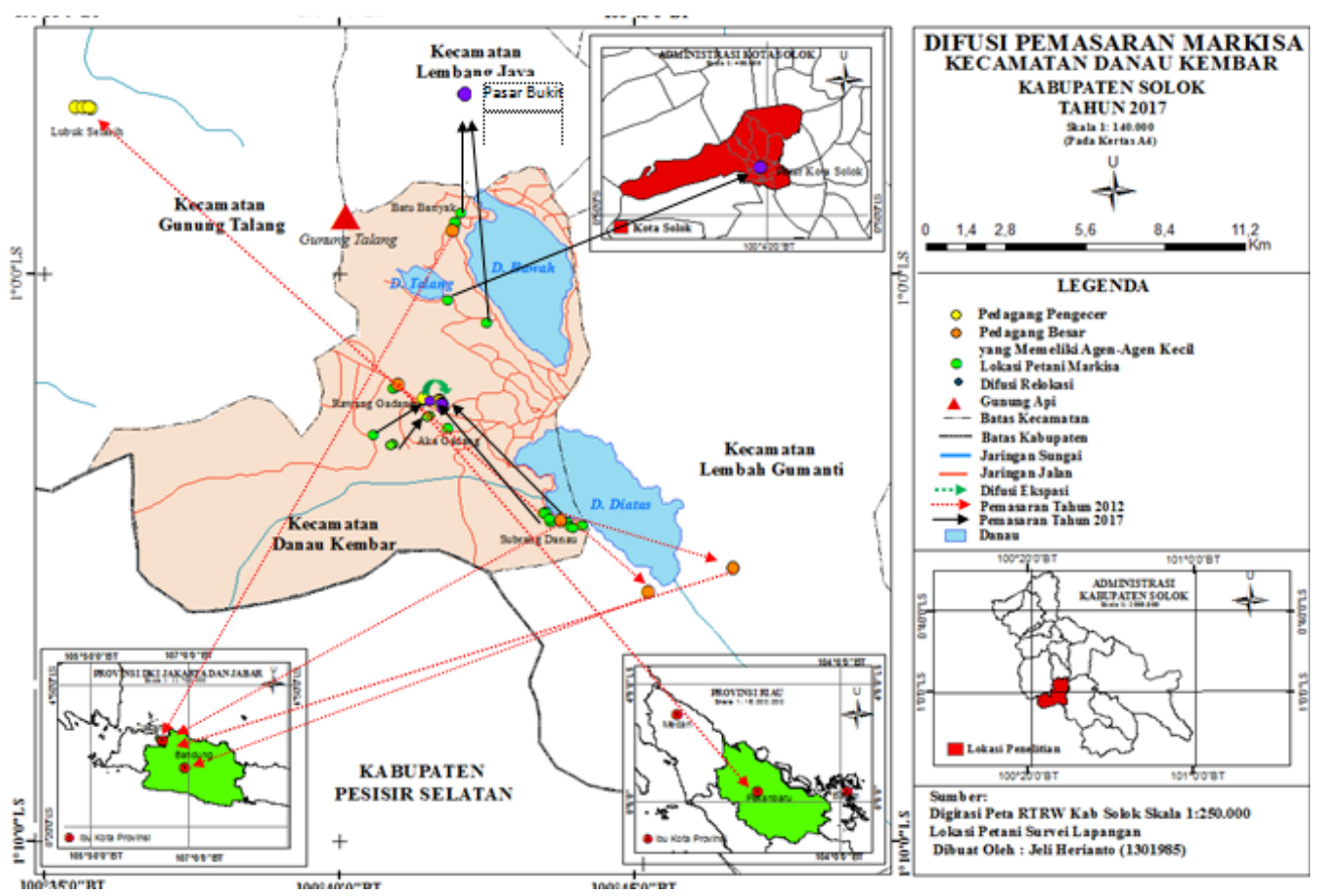

Sumber: Data Primer 2017

Berdasarkan pada peta diatas terlihat daerha-daerah pemasaran markisa di Kecamatan Danau Kembar. Dapat dilihat pada tahun 2012 arah pemasaran markisa hingga Jakarta dan Bandung serta Pekanbaru namun seiring terjadinya penurunan produksi markisa di tingkat petani maka arah pemasaran markisa pindah ke daerah-daerah sekitar kecamatan Danau Kembar seperti menuju Pasar yang ada di Kecamatan Lembang Jaya, serta daerah daerah wisata yang ada disekitar kecamatan. Artinya terjadi difusi relokasi. Difusi Relokasi/ Penampungan (relocation diffusion) merupakan proses yang sama dengan penyebaran keruangan dimana informasi atau material yang didifusikan meninggalkan daerah yang lama dan berpindah atau ditampung di daerah yang baru. Sementara itu tempat pemasaran yang pada awalnya hanya ada beberapa tempat pemasaran namun pada tahun 2017 sudah muncul tempat-tempat pemasaran baru disekitar tempat pemasaran lama sehingga terjadi difusi ekspansi dengan tipe menyebar di daerah tersebut.

\section{PENUTUP \\ Kesimpulan}

Berdasarkan hasil penelitian dilakukan dilapangan, maka dapat disimpulkan tentang kajian geografis budidaya Tanaman Markisa di Kecamatan Lembah Gumanti dan Kecamatan Danau Kembar adalah :

1. Aksesibilitas menuju lahan markisa berada dalam kondisi : a) sebagian besar petani menempuh jarak 0-2,3 km di Kecamatan Lembah Gumanti, sedangkan di Kecamatan Danau Kembar sebagian besar menempuh jarak 2,3 -4,6 km. b) Kondisi jalan menuju lahan di kedua kecamatan umumnya jalan tanah setapak. c) Biaya perjalanan yang dikeluarkan petani menuju lahan di dikedua kecamatan tidak ada. d) Waktu 
tempuh menuju lahan di kedua kecamatan pada umumnya membutuhkan waktu 20 - 60 menit.

2. Aksesibilitas menuju pemasaran berada dalam kondisi a) jarak pemasaran markisa dikedua kecamatan umumnya antara 0-3,3 $\mathrm{km}$ b.) Kondisi jalan menuju pemasaran di Kecamatan Lembah Gumanti 47,4\% melewati jalan tanah setapak, sementara Kecamatan Danau Kembar 51,9\% melewati jalan tanah, lalu kerikil dan aspal. c) Biaya yang dikeluarkan petani melakukan pemasaran di dua kecamatan umumnya berada pada kisaran Rp. 20.000 - Rp 50.000. d) Waktu yang ditempuh setiap melakukan pemasaran di kedua kecamatan umumnya membutuhkan waktu 20-60 menit.

3. Pola difusi pemasaran markisa di Kecamatan Lembah Gumanti dan Kecamatan Danau Kembar termasuk kedalam pola difusi ekspansi (Ekspansion Diffusion) dengan tipe menyebar dan difusi Relokasi.

\section{Saran}

Berdasarkan hasil penelitian dan kesimpulan diatas, maka penulis memberi saran sebagai berikut:

1. Bagi masyarakat, perlunya membuka diri terhadap inovasiinovasi baru terkait usaha tani markisa serta menghindari daerahdaerah yang aksesibiliatasnya rendah dalam rangka membudidayakan markisa maupun saat pemasaran.

2. Bagi pemerintah, Perlunya perhatian khusus terhadap permasalahaan-permasalahaan petani markisa dengan kebijakankebijakan yang dapat mendudkung usaha tani markisa. Karna secara ekonomis usaha tani markisa sangat menjanjikan guna meningkatkan kesejahteraan hidup petani.

3. Penelitian ini terbatas pada gambaran aksesibilitas dan pola pemasaran markisa sehingga diperlukan adanya penelitian lanjutan terkait masalah markisa khususnya di Kabupaten Solok.

\section{DAFTAR PUSTAKA}

Arikunto. Suharni. 2006. Prosedur Penelitian. Jakarta : Rineka Cipta

Bappeda Sumbar. 2013. Sumatera Barat dalam Angka. Padang: Biro Pusat Statistik Sumatera Barat.

Bintarto, R dan Surastopo, Hadisumarno.. 1979. Metode Analisis Geografi.. Jakarta : LP3ES

Dinkes Provinsi Sumatera Barat. 2010. Laporan Tahunan, Padang: Dinkes Sumatera Barat.

Firdaus,M. 2010. Manajemen Agribisnis. Jakarta: PT Bumi Aksara.

Magribi, Muhammad. 2004. Aksesiblitas dan pengaruhnya terhadap pembangunan diperdesaan. Kendari : Jurnal Transportasi. Vol.4, No 2: :149-160

Miro, F. 2002. Perencanaan Transportasi. Jakarta: Airlangga

Sudjana, Nana. 2007. Penelitian dan Penilaian Pendidikan. Bandung : Sinar Baru

Syafrizal, Helmi. 2009. Bisnis perencanaan dan pengembangan. Medan: USU Press. 
Tamin, Ofyar Z. 2000. Perencanaan dan Pemodelan Transportasi. Bandung: ITB Bandung.

Undang-Undang No 13 tahun 2010 ayat 1 tentang tanaman holtikultura

Undang-Undang No 23 Tahun 2014 tentang pemerintahaan daerah

Zulkifli,Rauf. 2015. Menyusuri Jalan Setapak di Molutabu (JUT). Gorontalo: BP3K Kabila Bone 